\title{
Assessment of the spatio-temporal distribution of soil properties in East Kolkata wetland ecosystem (A Ramsar site: 1208)
}

\author{
$\mathrm{S} \mathrm{PaL}^{1,3, *}, \mathrm{~S} \mathrm{Manna}^{2}, \mathrm{~A} \mathrm{Aich}^{3}$, B Chattopadhyay ${ }^{3}$ and S K Mukhopadhyay ${ }^{4}$ \\ ${ }^{1}$ Department of Conservation Biology, Durgapur Government College, Durgapur 713 214, West Bengal, India. \\ ${ }^{2}$ School of Oceanographic Studies, Jadavpur University, Kolkata 700 032, West Bengal, India. \\ ${ }^{3}$ Government College of Engineering 83 Leather Technology, Salt Lake, LB-III, Kolkata 700098 , \\ West Bengal, India. \\ ${ }^{4}$ Hooghly Mohsin College, Hooghly, Chinsurah 712 101, West Bengal, India. \\ ${ }^{*}$ Corresponding author. e-mail: sudindgp1@gmail.com
}

The present investigation was made to characterize spatial and temporal variations in soil properties and to evaluate possible differences that could be dependent on the tannery effluent discharges, municipal sewage discharges, vegetation cover, soil settlement rate, crop rotation, etc. Soil total organic matter (TOM), cations like, Sodium (Na), Ammonium $\left(\mathrm{NH}_{4}\right)$, Potassium $(\mathrm{K})$, Calcium (Ca) and Magnesium $(\mathrm{Mg})$ contents in the bank soils and bottom sediments were recorded from seven different characteristic sites in East Kolkata wetland ecosystem, a Ramsar site (Ramsar site No. 1208). The profile maps were constructed by geostatistical methods to describe the spatial distribution as well as temporal variations of all the factors to identify the influences of composite wastewaters. The work was initiated to identify causes and consequences of the waste dumping in the concerned region for the past hundred years and thereby to suggest necessary precautionary measures to prevent further loss of soil quality.

\section{Introduction}

Organic matter plays a major role in wetland ecosystem. It affects various biochemical processes, chemical transport, bio-availability of nutrients and nutrient cycling. The soil organic matter (SOM) is also a very sensible indicator of climate, and it can also indicate climate changes (Xiao et al. 1999). SOM is also an important ecological entity of wetland ecosystems and it influences the productivity of these areas. In case of anaerobic respiration, organic matter decomposition is often incomplete. Therefore, lack of oxygen is one of the main factors determining plant detritus turnover. The organic matter is either produced from the wetlands itself and it gets accumulated in wetlands at different decomposition stages (Collins and Kuehl 2001; Holden 2005), or the organic matter comes from outside of the system creating a net retention of organic matter (Mitsch and Gosselink 2007). The chemical constituents of organic matter are categorized by nonhumic substances (carbohydrates, proteins, fats), phenolic substances (lignins and tannins) and humic substances (Stevenson 1994). The storage of organic matter, in other words, is the storage of carbon in an ecosystem. It is also to be kept in mind that in our ecosystem, the wetlands occupy only $4-6 \%$ of the earth's

Keywords. Total organic carbon; cations; Ramsar site; East Kolkata wetland; composite wastewater; geostatistical methods; spatial maps. 
land area (Matthews and Fung 1987; Aselmann and Crutzen 1989) but among 350-535 Gt carbon (Post et al. 1982; Gorham 1995; Mitra et al. 2005), corresponding to $20-25 \%$ of the world's organic soil carbon. So, assessment of percentage of SOM is necessary to adopt strategies for policy making, planning, and implementation processes for improving carbon storage of that area. Apart from this, it is very important to know the composition of SOM containing essential nutrients like $\mathrm{Na}, \mathrm{NH}_{4}, \mathrm{~K}, \mathrm{Ca}, \mathrm{Mg}$ in soil samples from the study area because all these nutrients have a major role in prokaryotic and eukaryotic growth, helping in proper cell division and elongation, cell wall development, metabolism, enzyme activity, etc. On the contrary, these cations prevent soil enzymes inhibition by interacting with organic matter (Reddy and Delaune 2008). Temperature is also one of the key regulators for biogeochemical process in a wetland ecosystem. Depending upon the seasons the temperature changes by which microbial activity, organic matter, decomposition rate are altered. Therefore, indepth understanding about these cations and organic matter concentration in spatio-temporal scale are very much needed to maintain the ecological and economical values of wetland ecosystems.

The East Kolkata Wetland (EKW) ecosystem, a globally focused wetland area, has been used sustainably for resource recovery and amelioration of toxic wastes (Chatterjee et al. 2006). Thereby, the concerned wetland area has gained much attention of the scientists from the stand point of ecosystem health and human health. The Kolkata city wastewater has been productively used in pisciculture and agriculture for the past several decades. On the journey through the wastewater carrying canals (Dry Weather Flow and Storm Water Flow canals), wastewater is productively used in pisciculture and as irrigation water in agricultural farms on garbage dumping. Spill-over wastewater from wastewater-fed fisheries and agricultural runoff are mixed with canal wastewater to influence the characteristics of the wastewater dramatically. Chattopadhyay et al. (2004) recorded spatial and temporal changes of physico-chemical factors like air and water temperature, water velocity, $\mathrm{pH}$, conductivity, TDS, TSS, DO, nitrate, phosphate, sulfate, chlorides, BOD and COD of water of four different sites on the wastewater carrying canal of the EKW ecosystem. The EKW produced 10,915 metric tons of fish annually along with the garbage farming and yielded nearly $370,650 \mathrm{~kg} \mathrm{ha}{ }^{-1} \mathrm{Y}^{-1}$ vegetables, which amounts to 150 metric tons of vegetables daily (Chatterjee et al. 2006). Wastewater in the EKW areas has been used for wastewater-fed fish farming and as irrigation water for garbage farming for the last several decades with a high risk of contamination with waste elements. Chatterjee et al. (2006) studied the occurrence of six elements, namely, $\mathrm{Cr}, \mathrm{Mn}, \mathrm{Fe}, \mathrm{Cu}, \mathrm{Zn}$ and $\mathrm{Pb}$ in water, bottom soil of the wastewaterfed fish ponds together with the accumulation of these elements in the tissues of two cichlid fish species cultivated in wastewater-fed fish ponds of EKW. Information on soil characteristics and the amelioration capacity of the vast economically important EKW region is, thereby, thought to be extremely important from the standpoint of ecosystem services. No such systematic works on soil quality are on record from the concerned wetland ecosystem. Therefore, the explicit objective of this study is to identify the changes in spatial and temporal patterns of physical and chemical properties of soil with special reference to agriculturally important factors like soil total organic matter (TOM), cations like, Sodium (Na), Ammonium $\left(\mathrm{NH}_{4}\right)$, Potassium (K), Calcium (Ca) and Magnesium $(\mathrm{Mg})$, involving different seasons of the year. To show this spatio-temporal variation more minutely, with the help of global positioning systems, geographic information systems, and geostatistics, the interpolation and extrapolation maps are constructed. The geostatistical methods, formulated mathematically, allow the random variation in soil properties. This method ensures that the prediction error is minimum for the observed variables and it also provides confidence for the predictions of unsampled locations. In addition, the process quantifies the detrimental impact of anthropogenic activity on wetlands, the areas difficult to approach physically, at spatio-temporal scale, and provides valuable information on the areas concerned to design strategies for wetland conservation and restoration projects. Though such landscape-scale assessments have attracted little attention in India, a good number of published information is available from different parts of the globe (Craft and Richardson 1998; DeBusk and Reddy 1998, 2003; DeBusk et al. 2001; Bruland and Richardson 2004, 2005; Grunwald et al. 2005; Corstanje et al. 2006). Such understanding would help us to plan future research efforts, aiming at wise use of the EKW by the way of sustainable pisciculture and agricultural practices on the one hand and on the other, to record seasonwise and sitewise sequestration of carbon and other pollutants spewed by the city of Kolkata.

\section{Materials and methods}

\subsection{Study area and site description}

The East Kolkata Wetland (EKW; lat. $22^{\circ} 25^{\prime}-$ $22^{\circ} 40^{\prime} \mathrm{N}$; long. $88^{\circ} 22^{\prime}-88^{\circ} 35^{\prime} \mathrm{E}$ ), currently a Ramsar site (No. 1208), is widely considered as a unique 
site which demonstrates the natural reduction of toxicity by the biota and physico-chemical interactions. The elevation profile of the study area ranged between 1 and $5 \mathrm{~m}$, with a gradual sloping from west to east. This causes natural unidirectional flow of sewage water in EKW. The EKW has received untreated municipal and industrial wastewater from the city through different canals and channels for the last 100 years. The total area of 12,741 ha, comprised water spread of an area of 4728 ha, degraded water spread 1124 ha, agricultural land 4959 ha, garbage farming area 602 ha and urban and rural settlement nearly 1326 ha. Huge composite industrial effluent $\left(50,000 \mathrm{~m}^{3}\right.$ $\mathrm{d}^{-1}$ ) mixed with city sewage from Kolkata city is discharged, without any pre-treatment and nearly 2000-3000 metric tons of solid wastes in different forms are being deposited daily in the EKW areas. The EKW, thus, receives enormous amount of nutrients that support rich and luxuriant primary producers on the one hand and trap unused carbon in different physico-chemical states. Chemical compounds, especially from leather industry (Mukherjee et al. 2013), in the abiotic environment of the EKW are also important in sequestering carbon, other elements, and nutrients in the EKW.

Depending upon the different wastewater inputs, the canal's characteristics were changed which might have affected the surrounding area. Based on the wastewater input and use, seven different characteristic sites (with roughly overlapping boundaries) are taken from where the soils are collected. Site-I is located around $1 \mathrm{~km}$ away from Tangra tannery agglomerate (China town) of Kolkata from which a canal carries raw composite tannery effluent; Site-II is the area of tannery effluent-fed fish ponds, adjacent to Site-I; Site-III is located around $8 \mathrm{~km}$ away from Site-I where the tannery effluent is being mixed with municipal wastewater and other industrial effluents coming through Ballygunge Pumping Station; Site-IV is the area of wastewater-fed fish ponds at Chowbaga, nearly $0.5 \mathrm{~km}$ away from Site-III; Site-V is near Kolkata Leather Complex (KLC), Bantala, around $15 \mathrm{~km}$ away from Site-I; this is the area where further composite tannery effluents from the KLC are mixed with heterogeneous wastewater; Site-VI is located between Site-IV and Site-VII, nearly $30 \mathrm{~m}$ away from Site-I. Site-VII, nearly $40 \mathrm{~m}$ away from the Site-I, where effluents are discharged finally into the Kultigong River (figure 1). The major canals from which EKW has received different waste water are shown in figure 2 .

\subsection{Soil sampling and analysis}

Soils samples are sampled from seven different selected site areas. The sampling has been done
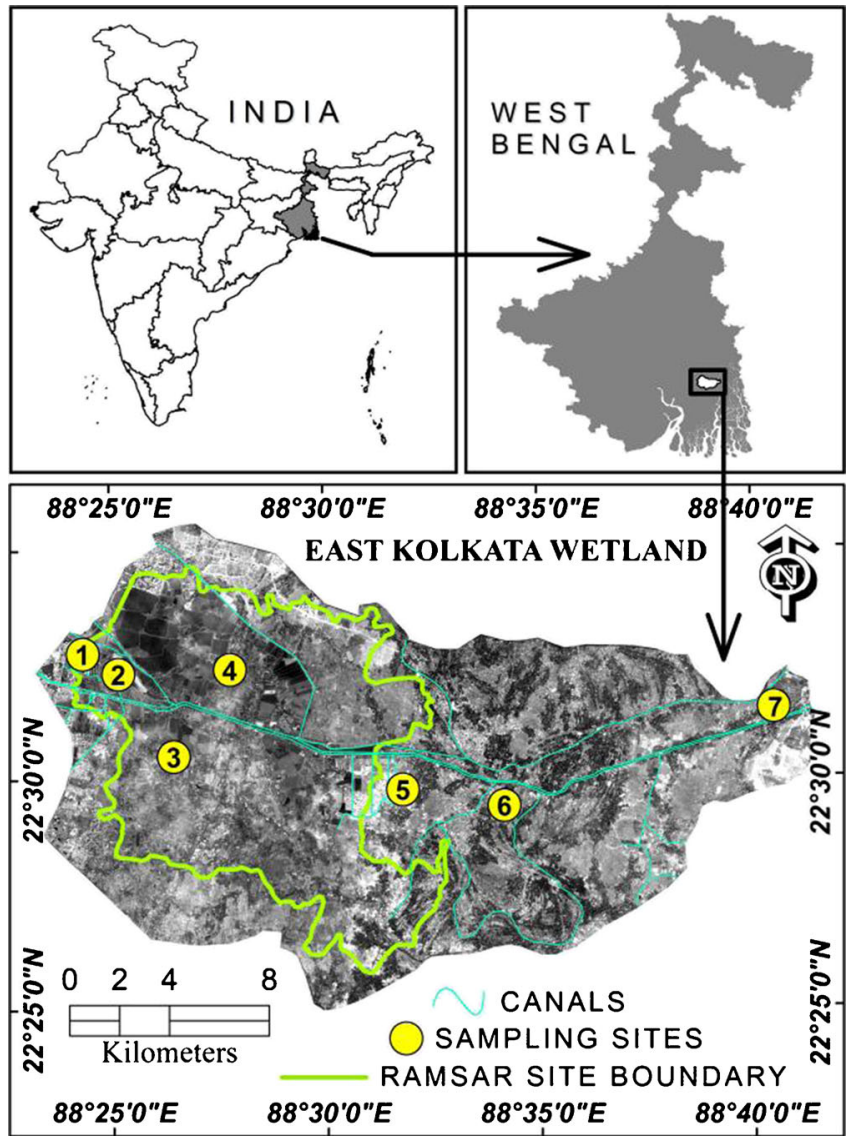

Figure 1. Site map of East Kolkata wetland ecosystem. (India and West Bengal maps are not in scale.)

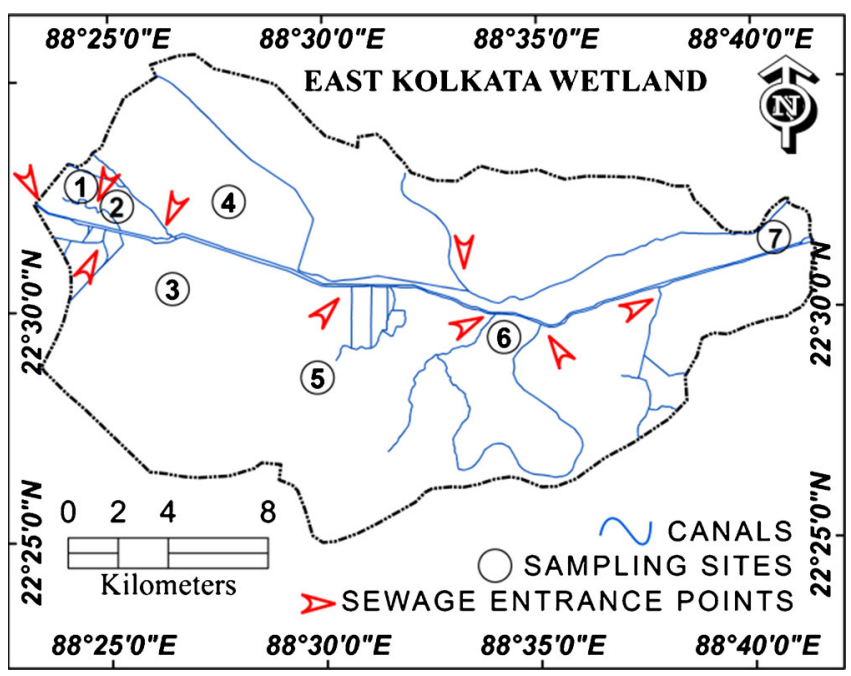

Figure 2. Entry points of sewage in East Kolkata wetland ecosystem.

randomly, 3-4 km radius around each demarcated site. Bank soils of the margin of the wastewater carrying canals and from agricultural farms are collected from the upper $2 \mathrm{~cm}$ layer. Collected soil samples are dried at $60^{\circ} \mathrm{C}$ in a hot air oven. Dried soil samples are hand picked off visible roots and 
leaves and then ground into a powder and sieved with a $2 \mathrm{~mm}$ sieve. The percentage of soil total organic carbon is determined by Walkley-Black method, and by multiplying with 1.724 the percentage of soil organic matter has been derived (Eaton et al. 1995). Cations like Sodium (Na), Ammonium $\left(\mathrm{NH}_{4}\right)$, Potassium $(\mathrm{K})$, Calcium (Ca) and Magnesium $(\mathrm{Mg})$ are determined by Methrom Ion Exchange Chromatograph (Jackson 2000).

The statistical analysis like single linkage Euclidian distance of different variables by STATISTICA w 5.0 software and all the bar graphs with standard deviation are made by using Origin 6.1 software.

\subsection{Generation of spatial interpolation maps}

The spatial interpolation maps are generated by using ArcGIS 9.3 software. The surface soil is analysed using deterministic method to generate spatial maps of six different parameters. Since the terrain has an unchanged elevation gradient with respect to mean sea level and the study is made in a small area covering a radius of $25 \mathrm{~km}$, the effects of wastewater on the soil on either side of the canals passing through EKW for use of wastewater in pisciculture and agriculture are assessed with systematic sampling of seven zones through three seasons, namely, pre-monsoon, monsoon and post-monsoon. The maps were produced using exact interpolator where the spatially predicted values are similar to measured values. We used radial basis functions and the functions are described in Bishop (1995). Further descriptions of radial basis functions and their relationships to splines and kriging can be found in Cressie (1993) and Chiles and Delfinder (1999).

The wetlands and settlements including manmade structures were mapped from IRS P6 LISS 4 image of 2012. The satellite image was geometrically and atmospherically corrected for this delineation. Normalized Differential Vegetation Index - NDVI (Tucker 1979) has been used efficiently for wetland studies (Ozesmi and Bauer 2002) and also in our study for preparing landuselandcover map of EKW. The image was taken in February which was post-harvest period for the study area and also atmospheric interferences remained less during that time. The base map with fewer classes was prepared using unsupervised classification on NDVI image. Post-classification accuracy was assessed by ground truthing, using ground control points, which were collected from study area acquired by Garmin GPS 72 and visual interpretation from Google Earth. The new resultant classes were merged to produce new image with two classes; 'water bodies and settlement' and 'others'. Water bodies and settlement comprised of all the surface water features and man-made structures including buildings, culverts, metal and concrete roads. The final image was used as a mask on the interpolation maps.

\section{Result}

According to figure 2(a), the TOM is very much high at Site-I as well as at Site-II regions. The average percentage of TOM at Site-I and SiteII are $3.36 \%$ and $2.54 \%$ in pre-monsoon season (figure $3 \mathrm{a}$ ), $3.35 \%$ and $2.99 \%$ during the monsoon (figure $4 \mathrm{a}$ ), $3.88 \%$ and $2.75 \%$ in post-monsoon (figure 4a). A moderate percentage of TOM is observed in Site-III and Site-IV region, which is in between $2.26 \%$ and $3.06 \%$. After that the average percentage of TOM in Site-V and Site-VI lies between $2.00 \%$ and $2.70 \%$ and except in premonsoon season $(2.77 \%)$ it is minimum at SiteVII $(1.78 \%-1.85 \%)$. The variations of TOM due to seasonal changes are not too noticeable. In premonsoon, the average TOM of all seven sites are $2.78 \pm 0.30 \%$ followed by monsoon $2.58 \pm 0.75 \%$ and post-monsoon $2.54 \pm 0.53 \%$ (figure $5 \mathrm{a}$ ).

The average sodium $(\mathrm{Na})$ concentration at SiteI is very high $(686.15-4183.19 \mathrm{mg} / \mathrm{kg})$, followed by Site-VII (404.23-1123.26 mg/kg). At the intermediate four locations, Site-II (543.08-899.24 mg/kg); Site-III (301.95-880.16 mg/kg); Site-IV (315.45$1285.63 \mathrm{mg} / \mathrm{kg})$; Site-V (344.19-1021.68 mg/kg); Site-VI (282.05-1062.49 mg/kg), the Na concentrations are always noted to be less than that at Site-I and at Site-VII. A marked seasonal variation is noticed in $\mathrm{Na}$ concentration. The average $\mathrm{Na}$ concentration in all seven sites of EKW is premonsoon $>$ monsoon $>$ postmonsoon (figures $3 \mathrm{~b}$, $4 \mathrm{~b}$ and $5 \mathrm{~b})$.

The $\mathrm{NH}_{4}$ concentration does not vary too much throughout the year. The average concentration of $\mathrm{NH}_{4}$ is high in Site-III $(82.81-238.98 \mathrm{mg} / \mathrm{kg})$ followed by Site-I $(127.22-159.61 \mathrm{mg} / \mathrm{kg})$ and SiteII $(100.03-121.48 \mathrm{mg} / \mathrm{kg})$. The temporal variation of average concentration of $\mathrm{NH}_{4}$ in all seven sites are pre-monsoon $>$ monsoon $>$ post-monsoon, i.e., $155.01 \pm 25.69 \mathrm{mg} / \mathrm{kg}>120.96 \pm 57.87 \mathrm{mg} / \mathrm{kg}>$ $85.22 \pm 26.97 \mathrm{mg} / \mathrm{kg}$ (figures $3 \mathrm{c}, 4 \mathrm{c}$ and $5 \mathrm{c}$ ).

The average $\mathrm{K}$ concentration significantly shows higher value in Site-IV (152.88-249.99 mg/kg), followed by Site-II (103.94-217.41 mg/kg) where most of the large water bodies of EKW are located. The $\mathrm{K}$ concentration of other sites is: Site-I (79.83$116.9 \mathrm{mg} / \mathrm{kg})$; Site-III (76.41-88.88 mg/kg); Site-V (62.88-181.27 mg/kg); Site-VI (43.7-169.2 mg/kg) and Site-VII $(56-200.16 \mathrm{mg} / \mathrm{kg})$. A negligible difference has been noted for $\mathrm{K}^{+}$concentrations during the three seasons of investigation (figures $3 \mathrm{~d}$, $4 \mathrm{~d}$ and $5 \mathrm{~d})$. 

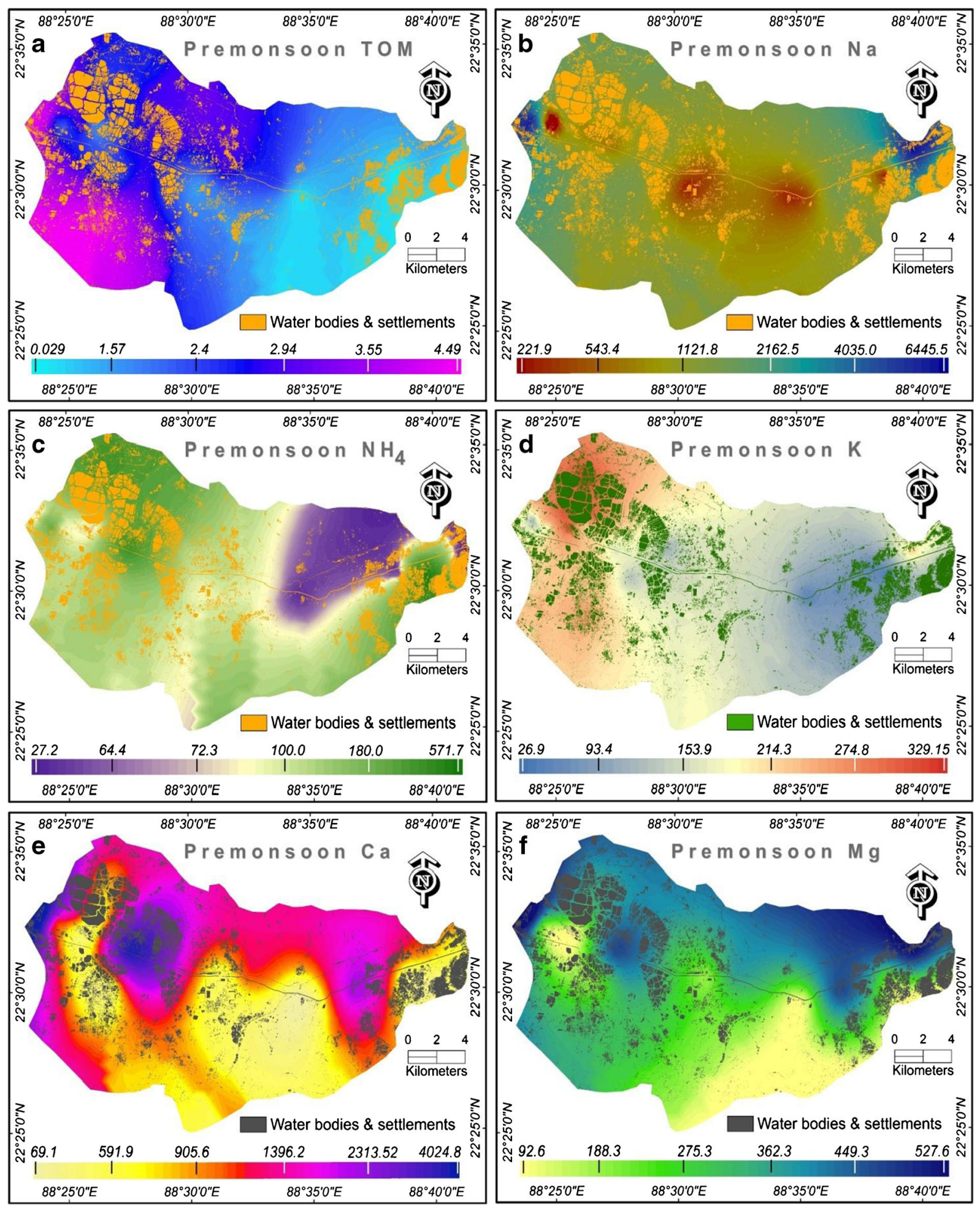

Figure 3. (a-f) Maps of spatio-temporal pattern of six different factors in soil of East Kolkata wetland ecosystem during pre-monsoon.

A significant amount of $\mathrm{Ca}$ is present in EKW soil. The $\mathrm{Ca}^{+}$concentration is always high in all three seasons studied and the extent of fluctuations is not distinguishable. Site-I contains 2265.6-2568.81 mg/kg followed by Site-III $(1404.26-2201.7 \mathrm{mg} / \mathrm{kg})$ and Site-V
(928.64-1274.67 mg/kg). The Ca concentrations of large water bodies of surrounding area are Site-II (725.33-989.03 mg/kg) and Site-IV (737.2$934.06 \mathrm{mg} / \mathrm{kg}$ ). Perceptible differences of average Ca concentrations are noted between pre-monsoon and the other two seasons (figures 3e, $4 \mathrm{e}$ and 5e). 

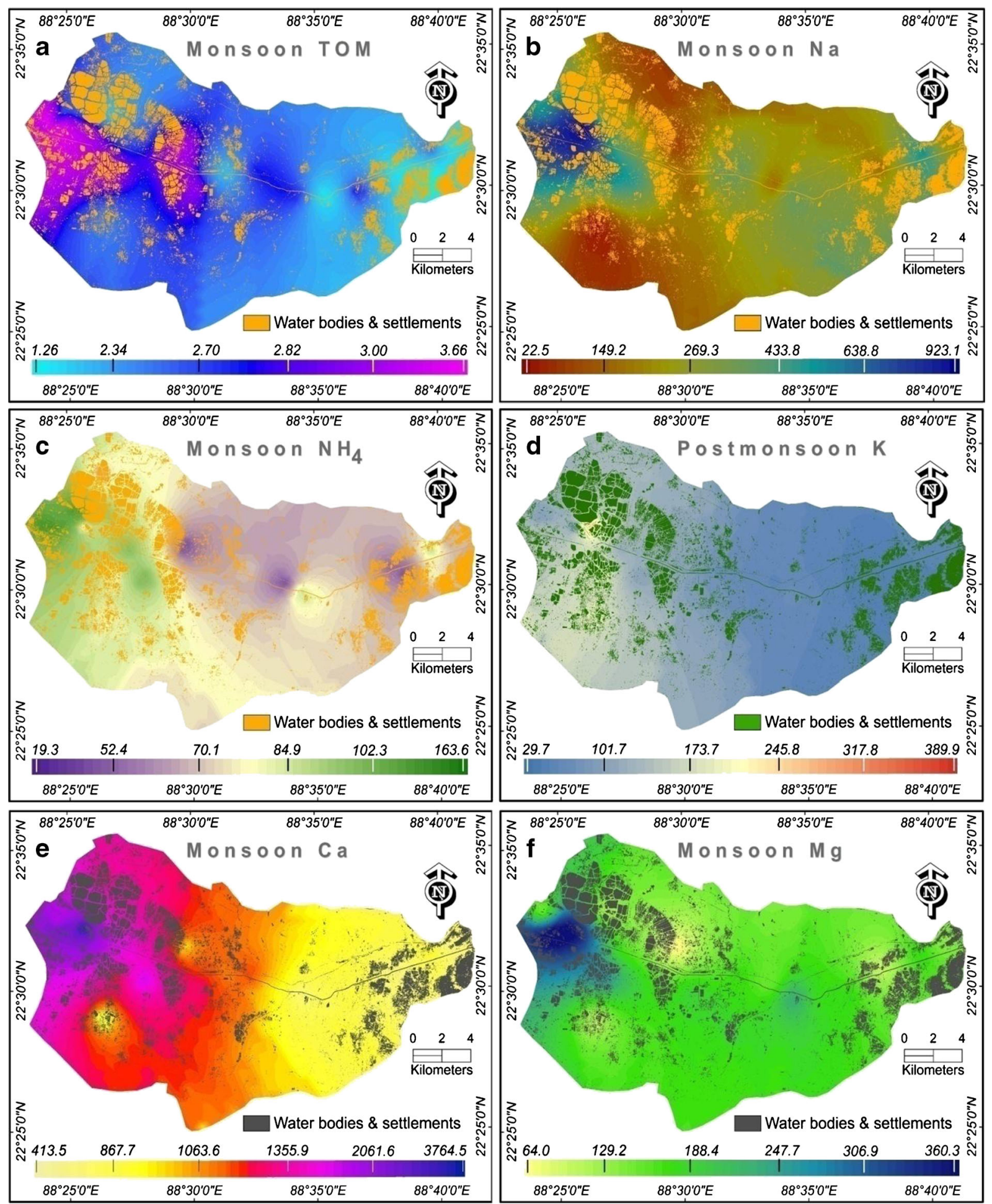

Figure 4. (a-f) Maps of spatial variation of six different parameters in soil of East Kolkata wetland ecosystem during monsoon.

$\mathrm{Mg}$ is another constituent of most agricultural lime. Predictable in Site-I (250.95-349.38 mg/kg) Ca content is higher than in others except SiteIII in monsoon. The average $\mathrm{Mg}$ concentrations of all sites in all three seasons are Site-II (151.03$230.18 \mathrm{mg} / \mathrm{kg})$; Site-III (147.4-370.08 $\mathrm{mg} / \mathrm{kg})$;
Site-IV (168.22-211.85 mg/kg); Site-V (170.95$255.81 \mathrm{mg} / \mathrm{kg})$; Site-VI (138.98-239.2 mg/kg); Site-VII (145.98-239.1 $\mathrm{mg} / \mathrm{kg})$. During premonsoon $(251.15 \pm 43.7 \mathrm{mg} / \mathrm{kg})$ and post-monsoon $(169.92 \pm 37.58 \mathrm{mg} / \mathrm{kg})$, the difference among the seven sites is not significant; significant differences 

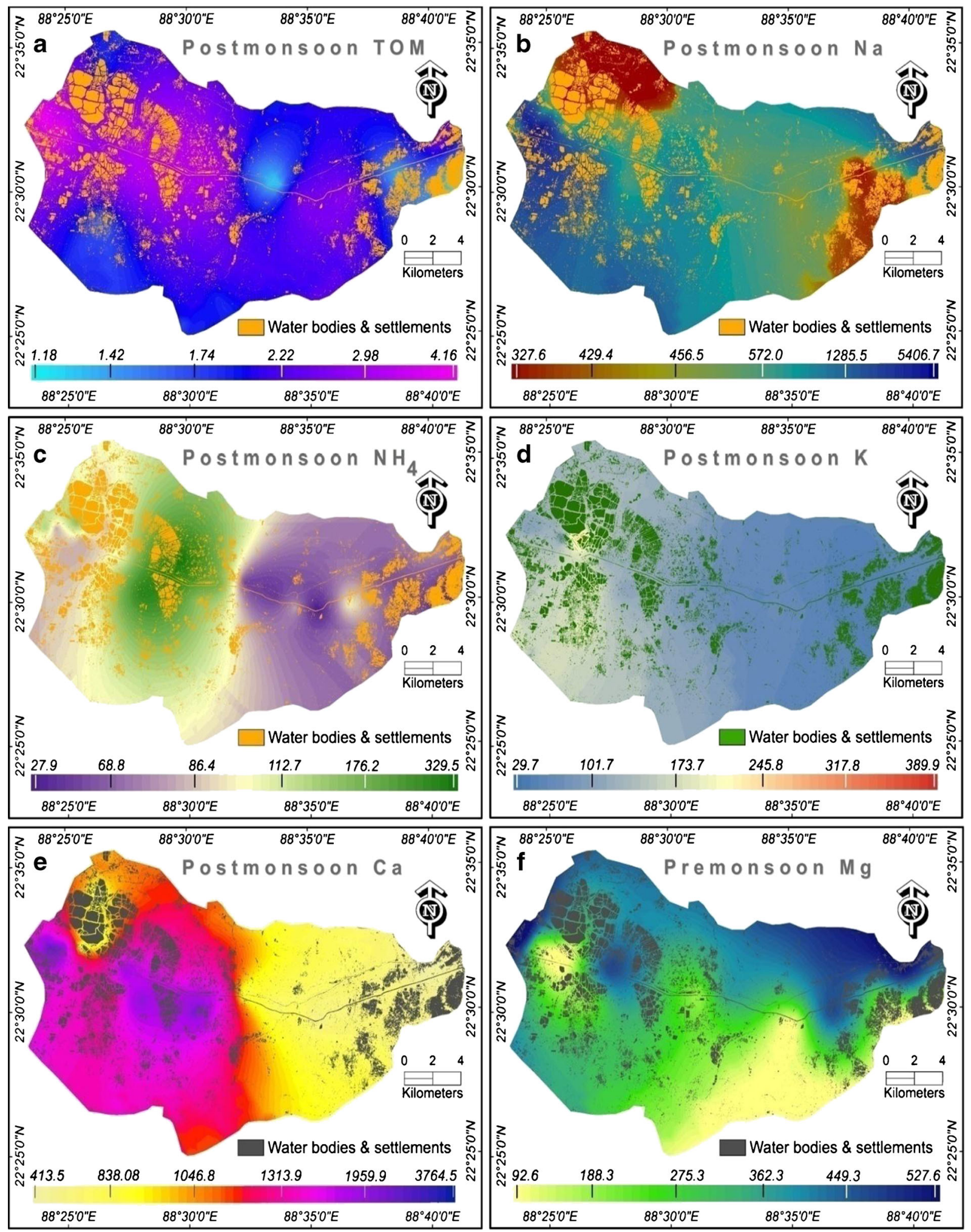

Figure 5. (a-f) Maps of spatial variation of six different parameters in soil of East Kolkata wetland ecosystem during post-monsoon.

are noticed only in monsoon $(231.7 \pm 96.89 \mathrm{mg} / \mathrm{kg})$ (figures 3f, 4f, and 5f).

Geostatistical methods produce only maps for the surface soil so as to give a soil profile of
EKW. The bottom soils of water bodies and canals are also analysed. The soil organic matter load in Site-I (3.40-4.07\%) was highest in all these seasons. Unlike SOM, other chemical variables 
in bottom soils were also relatively high in premonsoon, viz., $\mathrm{Na}(2458.8 \pm 1903.6 \mathrm{mg} / \mathrm{kg}) ; \mathrm{NH}_{4}$ $(174.37 \pm 97.49 \mathrm{mg} / \mathrm{kg}) ; \mathrm{K}(178.17 \pm 131.17 \mathrm{mg} / \mathrm{kg})$; $\mathrm{Ca}(2111.7 \pm 1504.8 \mathrm{mg} / \mathrm{kg}) ; \mathrm{Mg}(421.75 \pm$ $112.01 \mathrm{mg} / \mathrm{kg})$ and lowest in monsoon, $\mathrm{Na}(697.78$ $\pm 225.22 \mathrm{mg} / \mathrm{kg}) ; \mathrm{NH}_{4}(111.66 \pm 41.94 \mathrm{mg} / \mathrm{kg})$; $\mathrm{K} \quad(106.15 \pm 42.72 \mathrm{mg} / \mathrm{kg}) ; \mathrm{Mg}(273.92 \pm$ $60.88 \mathrm{mg} / \mathrm{kg})$ except Ca $(1504.8 \pm 491.59 \mathrm{mg} / \mathrm{kg})$ which is lowest in post-monsoon (1378.1 \pm $548.66 \mathrm{mg} / \mathrm{kg})$.

\section{Discussion}

Organic matter is added to wetlands from both internal and external sources. The internal sources include the dead parts of macrophytes, detrital matter from algal and microbial mats and the below ground portion such as roots and rhizomes (Reddy and Delaune 2008). The external sources are mostly municipal sewage water and industrial wastewater. So, it may be pointed out that the high value of TOM in Site-I and Site-II, is due to the presence of the raw tannery effluent carrying canal and the tannery effluent-fed fish ponds in those regions. Similarly, the tannery effluent, municipal wastewater and industrial wastewater are mixed at Site-III and the mixed wastewater is used at SiteIV for pisciculture and agriculture, causing moderate availability of TOM at both the sites. From the previous study of water characteristics of EKW (Chattopadhyay et al. 2004), a gradual decrease was recorded after Site-III region. Possibly due to relocation of tanneries at Bantala (Kolkata Leather Complex), the entry of tannery effluent in Site$\mathrm{V}$ causes the TOM content to be high. Similarly, the high TOM content at Site-VI may be due to the agricultural runoff water. The lower percentage of TOM in Site-VII is possibly due to strong tidal effects and lack of wastewater sources in this region.

Sodium is a highly important nutrient of an ecosystem. The availability of $\mathrm{Na}$ is dependent on the reaction rate between soil solutions and exchangeable phases of $\mathrm{Na}$, which is strongly dependent on the type of clay minerals present (Li and Ji 1992). As raw tannery effluent contains sodium chloride used in tannery operation called salt-pickling, the Na concentration is high in SiteI and in Site-VII, the direct influence of tides, where saline water containing sodium salt periodically flushes the location, makes the $\mathrm{Na}$ concentration high. In pre-monsoon periods the average air temperature is noted above $38^{\circ} \mathrm{C}$, therefore, the evaporation rate is high and as a consequence, a high $\mathrm{Na}$ concentration is recorded in pre-monsoon periods (figure $3 \mathrm{~b}$ ). In the monsoon season, perhaps due to heavy rainfall, $\mathrm{Na}$ drips downwards from surface soil and is also flushed with runoff. A marked decrease at all seven sites is due to such Na removal from soil surface during monsoon (figure $4 \mathrm{~b}$ ). In the post-monsoon season, most of the EKW areas are used for agriculture and $\mathrm{Na}$ uptake as an essential nutrient for plant growth may be envisaged. Thereby, may be the uptake of $\mathrm{Na}$ by cultivated plants reduces the Na concentration in soil in post-monsoon periods (figure $5 \mathrm{~b}$ ).

Similar to $\mathrm{Na}$, the spatial variation of other cations like ammonium $\left(\mathrm{NH}_{4}\right)$, potassium $(\mathrm{K})$, Calcium (Ca), and Magnesium ( $\mathrm{Mg}$ ) show more or less the same general pattern. Barshad (1951) explains that when ammonia reaches the soil surface, it reacts with water and gets transformed into ionic form ammonium $\left(\mathrm{NH}_{4}^{+}\right)$. This $\mathrm{NH}_{4}$ disassociates or it is nitrified into nitrite $\left(\mathrm{NO}_{2}^{-}\right)$or nitrate $\left(\mathrm{NO}_{3}^{-}\right)$releasing $\mathrm{H}^{+}$ions into the soil. If not, then it is transformed into methane which is removed from the soil by runoff or leaching. The uses of ammonium chloride and ammonium sulfate in the tanning process are the main sources of $\mathrm{NH}_{4}$ of EKW ecosystem. During the pre-monsoon season, at Site-V to Site-VII, the $\mathrm{NH}_{4}$ concentration is low which may be due to gradual filtration by EKW ecosystem (figure 3c). The concentration is high during monsoon at all sites possibly due to runoff on either side of the canal area and is comparatively low at agricultural field (figure 4c). The $\mathrm{NH}_{4}$ content is lower in the post-monsoon season than in the other two seasons, perhaps because the post-monsoon period is conducive for the growth of nitrifying bacteria (figure $5 \mathrm{c}$ ).

A very small amount (only $0.1-2.0 \%$ ) of $\mathrm{K}^{+}$from the total K pool is available for plants (Schroeder 1979; Bertsch and Thomas 1985). Much of the unavailable $\mathrm{K}$ is bound with other minerals. The $\mathrm{K}^{+}$are attracted to and held by negatively charged colloids (Sparks 1980) which make up the cation exchange capacity (CEC) of the soil and an increase of CEC increases the uptake of $\mathrm{K}^{+}$by plants. The $\mathrm{K}^{+}$is higher at Site-III and Site-IV where most of the large water bodies of EKW are located and may be with the increase of soil water contained in the adjacent areas, the CEC of the soil increases as pointed out by Sparks (2000). During the pre-monsoon season, high evaporation rate together with low soil water content probably causes less uptake of $\mathrm{K}^{+}$by plants and high $\mathrm{K}^{+}$ concentration in upper soil (figure $3 \mathrm{~d}$ ). However, during monsoon, rainfall increases the soil water content, but may be due to leaching and runoff the $\mathrm{K}^{+}$is low in surface soil (figure $4 \mathrm{~d}$ ). Further, due to high TOM, the $\mathrm{K}^{+}$that may be associated with TOM increases CEC and in turn causes an increase in plant uptake, thereby, decreasing $\mathrm{K}^{+}$ concentration of soil during post-monsoon periods (figure 5d). 
Calcium (Ca) is found with many of the pri- which plants can imbibe directly from soil. In mary and secondary minerals in the soil and it is tanning industry the sodium salt is used in high relatively insoluble. The $\mathrm{Ca}^{+}$is the soluble form quantities during industrial processing and due to

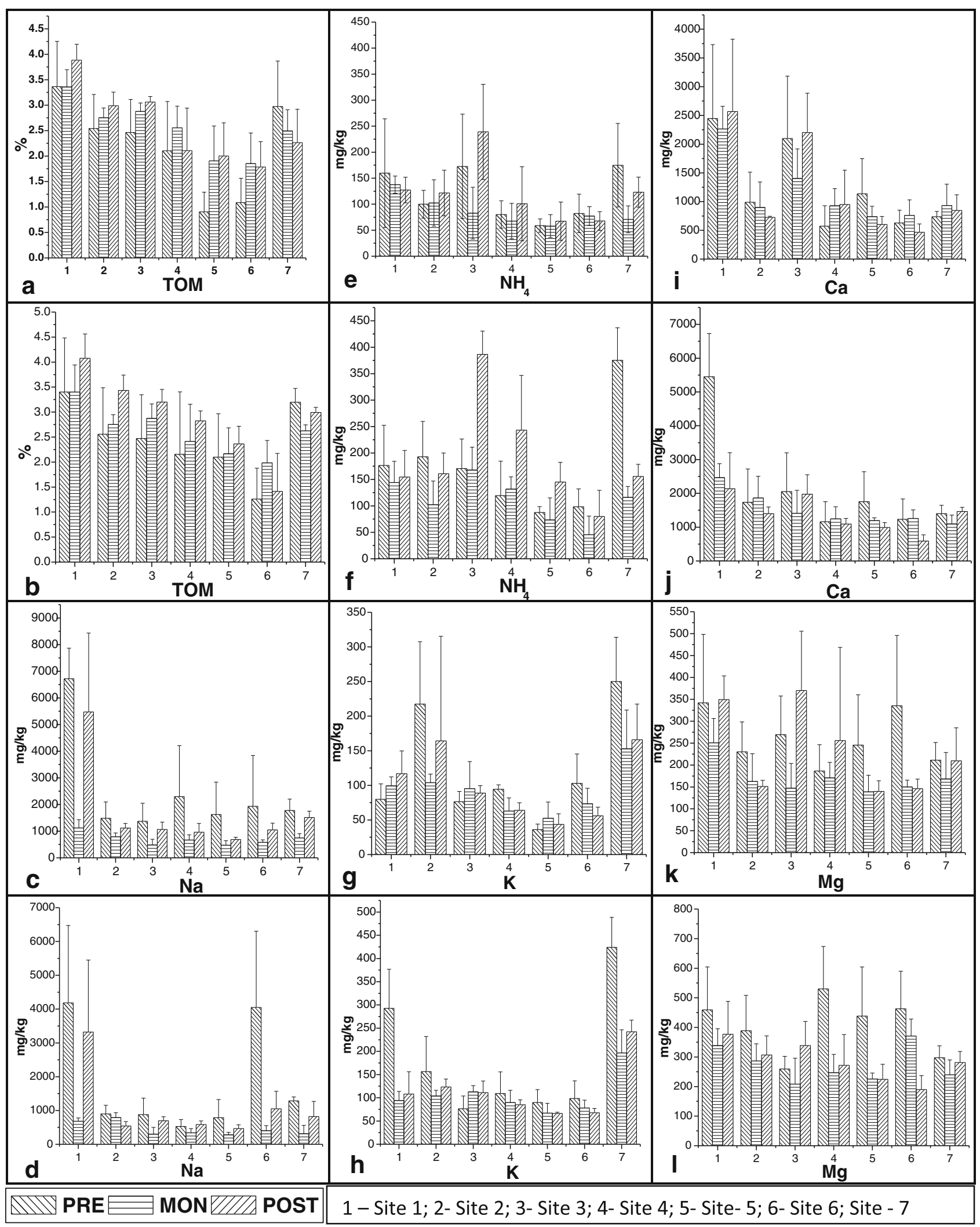

Figure 6. (a-l) Graphical representation of differences between bank soils and bottom soils of seven different sites for six different parameters. 
the discharge of composite tannery wastewater, the soils of EKW are enriched with sodium. Potassium salts, on the other hand, are much in use in agricultural practices as a fertilizer. For both these reasons, with the prevalence of $\mathrm{Na}^{+}$and $\mathrm{K}^{+}$in EKW soil, perhaps the $\mathrm{Ca}^{+}$is displaced with a reduction of uptake of $\mathrm{Ca}^{+}$by plants (Levy et al. 1988). Raw tannery effluent at Site-I and Site-II and also the effect of composite wastewater at Site-III and SiteIV with high load of waste Ca salts, account for high concentration of $\mathrm{Ca}$ in soil. The $\mathrm{Ca}^{+}$concentration gradually decreases from Site-I to Site-VII. The $\mathrm{Ca}^{+}$concentration is moderately high during pre-monsoon at Site-V and VI perhaps due to reintroduction of tannery effluent and agriculture wastewater. At Site-II and Site-IV, where the maximum number of water bodies are located at EKW, most of these are dried up to avoid the eutrophic condition during pre-monsoon and at that time an adequate amount of lime $\left(\mathrm{CaCO}_{3}\right)$ is used to neutralize soil acidity (figure $3 \mathrm{e}$ ). Probably as in case of other cations, the $\mathrm{Ca}^{+}$concentration decreases in soil as it is diluted and flushed out in the monsoon rain (figure 4e). However, during post-monsoon, it is slightly higher than in monsoon (figure 5e) as its retention in soil increases with receding monsoon flush off.

Soil $\mathrm{Mg}^{++}$adheres to soil colloidal complex. $\mathrm{Mg}^{++}$availability is related to soil CEC and it is in competition with other cations with $\mathrm{K}^{+}$being a stronger competitor (Levy et al. 1988). The soil adsorption of $\mathrm{Ca}$ is preferred over $\mathrm{Mg}$ (Sposito et al. 1986). During pre-monsoon, the difference among the seven sites is not significant; only at Site-I the Mg concentration is slightly high and tidal saline water which contains $\mathrm{Mg}$-salt enriches the soil contained at the adjoining areas of Site-VI and Site-VII (figure 3f). The composite wastewater at Site-III, which contains the municipal wastewater in bulk mixed with tannery wastewater, is the possible cause for the presence of high amount of $\mathrm{Mg}^{++}$during pre-monsoon and monsoon seasons (figure 4f). In the post-monsson season, the $\mathrm{Mg}$ content of soil again increases in all the sites possibly due to the use of $\mathrm{Mg}$ salts (magnesium carbonate, epsom salt, Mg chelates) as plants nutrient and neutralizing agent to decrease soil acidity (figure 5f).

In temporal scale, depending upon the tannery effluent discharge, municipal sewage mixing, vegetation cover, soil settlement rate, the SOM was low in the monsoon due to heavy rainfall and soils were flushed out, both in the case of the bank through erosion and the bottom soil through stirring and that is why the standard deviation of mean data set was high in some cases. During other parts of the year, the SOM did not fluctuate much; slightly higher values in winter than summer were noted (figure 6a and b). Unlike SOM, other chemical variables in both bank and bottom soil, were also relatively high in the pre-monsoon season. In bottom soil, $\mathrm{Ca}, \mathrm{K}, \mathrm{Na}, \mathrm{Mg}$, and $\mathrm{NH}_{4}$ were present in moderately high concentrations during the postmonsoon season. It should be mentioned here that graphical representations of data given here were constructed on the mean of seven study sites for two years. Therefore, in case of Site-VI and SiteVII, the sampling time at these locations and the tidal activities affected the dataset for the seasonal changes of concentrations of variables under study (figure 6c-l).

Dendrogram showed the relationship between all seven sites with respect to the above-mentioned six parameters. For bank soil and agricultural field soils of EKW the water body surrounded region (Site-II and Site-IV) and reintroduction of leather waste and agricultural runoff area (Site-V and Site-VI) were clustered together. Untreated raw

a

Tree Diagram for 7 Variables

Single Linkage Euclidean distances Bank Soil
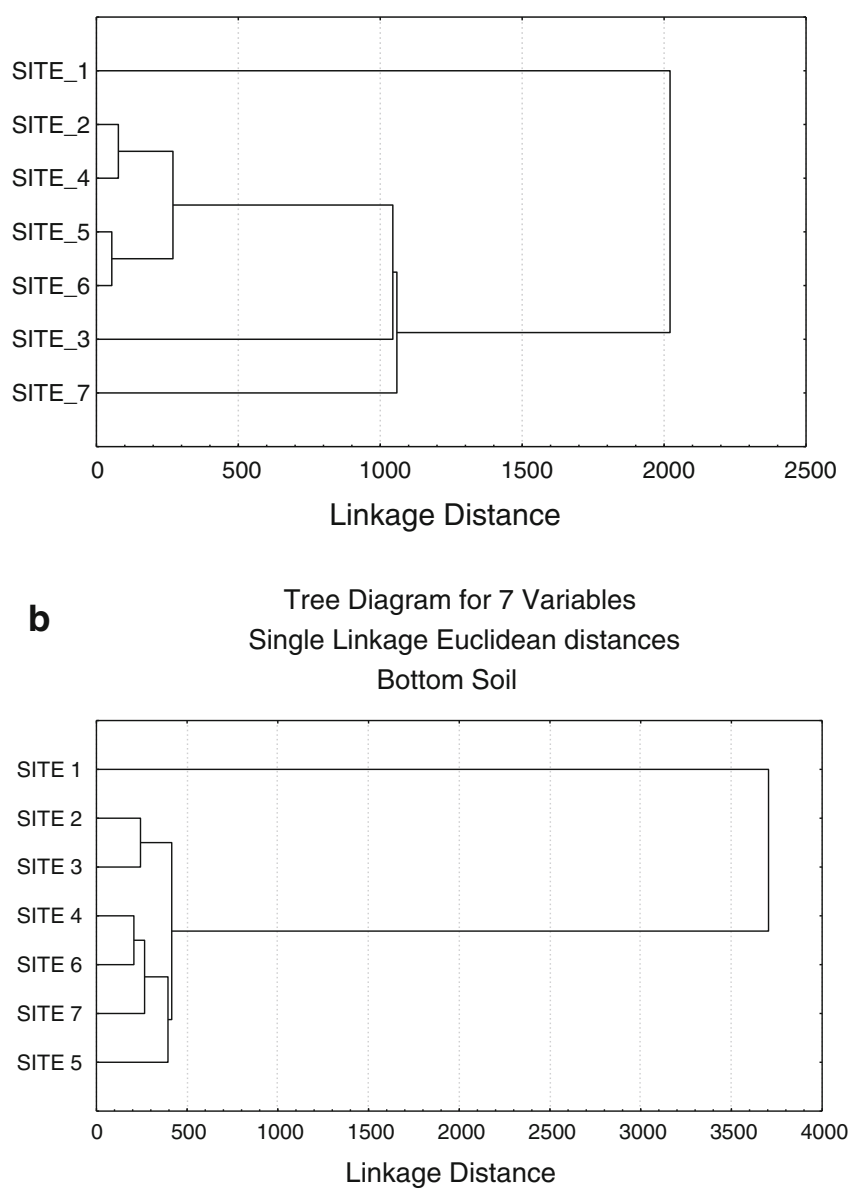

Figure 7. Dendrogram showing the results of hierarchical cluster analysis on the seven sites of East Kolkata wetlands under investigation depending on six factors of bank soils (a) and bottom soils (b). 
tannery effluent affected area (Site-I), composite waste water affected area (Site-III) and tidal saline water affected area (Site-VII) are distantly clustered with others (figure 7a).

Bottom soil conditions were directly correlated with the water physico-chemical conditions. SiteII was the tannery effluent-fed fish pond, where the water chemical conditions were stabilized in the bottom soil and from Site-I to Site-III the tannery wastewater was filtered through wetland soils. However, further mixing of municipal wastewater polluted the physico-chemical regimes and for that reason Site-II and Site-III were clustered together. Similar situation was noted at Site-IV and SiteVI. The reintroduction of tannery effluent at the Site-V, due to relocation of tanneries at Kolkata Leather Complex, near the Site- $\mathrm{V}$, formed a distant cluster separated from other clusters (figure $7 \mathrm{~b}$ ).

\section{Conclusions}

From the present study it was revealed that EKW has a great potential for the storage of organic matter in soil, and in turn the storage of carbon. The carbon storage efficiency of EKW give this economically as well as ecologically important wetland ecosystem an extra count towards conservation, sustainable development and the wise use of this region. It was evident from the present study that composite wastewater enhanced the concentration of cations in soil samples. In high concentrations, competition between these cations reduces their uptake through plants (Sposito et al. 1986; Levy et al. 1988) which directly affect the development of plant species and decrease the productivity of a system. EKW is very much economically important for pisciculture and agriculture operations. Thus certain control measures should be taken to avoid such accelerated waste discharge from this fragile ecosystem. Spatial distributions of chemical factors in surface soils showed noticeable variability in East Kolkata Wetland and clear distribution patterns were noted among the seven sites. This illustrates that spatially explicit model of sampling is needed to confirm the underlying variability of soil properties. In this study, in combination with the geostatistics, the spatially explicit sampling approach served as a model for the estimation of soil properties and it could also act as a guide for a comprehensive plan for the conservation of the fragile ecosystem, East Kolkata Wetlands. Detailed holistic studies could only make this natural effluent treatment plant, with which the Kolkata city's eastern backyard is blessed, more efficient in ameliorating hazardous wastes and would prove the area safe for productive use in agriculture and pisciculture by the introduction of proper management strategies.

\section{Acknowledgements}

First author thankfully acknowledges INSPIRE Division, Department of Science and Technology, Ministry of Science and Technology, Govt. of India for INSPIRE Fellowship and contingency grants. Authors express their thanks to Dr Anjan Biswas for providing the laboratory facilities and Dr Sugata Hazra for his valuable help. The authors also express gratitude to the Director of Public Instruction and the Director of Technical Education, Govt. of West Bengal, India, for co-operation and necessary support. SKM also expresses his gratitude to the University Grants Commission for a minor research grant with which a part of the present work has been supported.

\section{References}

Aselmann I and Crutzen P J 1989 Global distribution of natural freshwater wetlands and rice paddies, their net primary productivity seasonality and possible methane emissions; J. Atmos. Chem. 8 307-358.

Barshad I 1951 Cation exchange in soils: I. Ammonium fixation and its relation to potassium fixation and to determination of ammonium exchange capacity; Soil Sci. $\mathbf{7 7}$ 463-472.

Bertsch P M and Thomas G W 1985 Potassium status of temperate region soils. In: Potassium in agriculture (ed.) Munson R D, American Society of Agronomy, Madison, WI, pp. 131-162.

Bishop C M 1995 Neural networks for pattern recognition; Oxford Press, Oxford, 482p.

Bruland G L and Richardson C J 2004 A spatially explicit investigation of $\mathrm{P}$ sorption and related soil properties in two riparian wetlands; J. Environ. Qual. 33 785-794.

Bruland G L and Richardson C J 2005 Spatial variability of soil properties in created, restored and paired natural wetlands; Soil Sci. Soc. Am. J. 69 273-284.

Chatterjee S, Chattopadhyay B and Mukhopadhyay S K 2002 Bioaccumulation of metals in the East Kolkata Wetland Ecosystem; Aquat. Eco. Health Manag. 5(2) 191-203.

Chatterjee S, Chattopadhyay B and Mukhopadhyay S K 2006 Trace metal distribution in tissues if cichlids (Oreochromis niloticus \& O. mossambicus) collected from wastewater-fed fishponds in East Kolkata wetlands, a Ramsar site; Acta Ichthyol. et Piscat 36(2) 119-125.

Chattopadhyay B, Chatterjee S and Mukhopadhyay S K 2004 Seasonality in physico-chemical parameters of tannery wastewater passing through the East Kolkata wetland ecosystem; J. Soc. Leath. Tech. Chem. 88(1) 27-36.

Chiles J and Delfinder P 1999 Geostatistics. Modeling Spatial Uncertainty; John Wiley \& Sons, New York, 695p.

Collins M E and Kuehl R J 2001 Organic matter accumulation in organic soils. In: Wetland soils. Genesis, hydrology, landscapes, and classification (eds) Richardson J L and Vepraskas M J, Lewis, CRC, Boca Rato, pp. 137-162. 
Corstanje R, Grunwald S, Reddy K R, Osborne T Z and Newman S 2006 Characterization of the spatial distribution and uncertainty of soil properties in Water Conservation Area 1, South Florida; J. Environ. Qual. 35 938-949.

Craft C B and Richardson C J 1998 Recent and long-term organic soil accretion and nutrient accumulation in the Everglades; Soil Sci. Soc. Am. J. 62 834-843.

Cressie N 1993 Statistics for Spatial Data; John Wiley and Sons, New York, 900p.

DeBusk W F, Newman S and Reddy K R 2001 Spatiotemporal patterns of soil phosphorus enrichment in Everglades Water Conservation Area 2A; J. Environ. Qual. $301438-1446$.

DeBusk W F and Reddy K R 1998 Turnover of detrital organic carbon in a nutrient-impacted Everglades Marsh; Soil Sci. Soc. Am. J. 62 1460-1468.

DeBusk W F and Reddy K R 2003 Nutrient and hydrology effects on soil respiration in a northern Everglades marsh; J. Environ. Qual. 32 702-710.

Eaton A D, Clesceri L S and Greenberg A E 1995 Standard Methods of the Examination of Water and Wastewater; 19th edn, American Public Health Association, Washington DC.

Gorham E 1995 Biotic Feedbacks in the Global Climatic System (eds) Woodwell G M and MacKenzie F T, Oxford University Press, New York, pp. 169-187.

Grunwald S, Corstanje R, Weinrich B E and Reddy K R 2005 Spatial patterns of labile forms of phosphorus in a subtropical wetland; J. Environ. Qual. 35 378-389.

Holden J 2005 Peatland hydrology and carbon release: Why small scale process matters; Phil. Trans. Roy. Soc. 363 2891-2913.

Jackson P E 2000 Ion chromatography in environmental analysis; In: Encyclopedia of Analytical Chemistry (ed.) Meyers R A (Chichester: John Wiley \& Sons Ltd), pp. 2779-2780.

Levy G J, Van der Watt H V H and Du Plessis H M 1988 Effect of sodium-magnesium and sodium calcium systems on soil hydraulic conductivity and infiltration; Soil Sci. $146303-310$.

Li H Y and Ji G L 1992 Adsorption of potassium and sodium ions by variable charge soils; Pedosphere 2 245-254.

Matthews E and Fung I 1987 Methane emissions from natural wetlands: Global distribution, area and environmental characteristic of sources; Global Biogeochem. Cycles 1 $61-86$.

Mitra S, Wassmann R and Vlek L G P 2005 An appraisal of global wetland area and its organic carbon stock; Curr. Sci. 88(1) 25-35.

Mitsch W J and Gosselink J G 2007 Wetlands; 4th edn, Wiley, New York.

Mukherjee G, Debnath B, Mondal C and Chakraborty S 2013 Importance of carbon footprint with perspective to leather industry; J. Energy Environ. Sci. 127 177188.

Ozesmi S L and Bauer M E 2002 Satellite remote sensing of wetlands; Wetlands Eco. Manag. 10 381-402.

Post W M, Emanuel W R, Zinke P J and Stangenberger A G 1982 Soil carbon pools and world life zones; Nature 298 156-159.

Reddy K R and Delaune R D 2008 Biogeochemistry of Wetlands; Taylor \& Francis CRC Press, USA, pp. 119-134.

Schloeder C A, Zimmerman N E and Jacobs M J 2001 Comparison of methods for interpolating soil properties using limited data; Soil Sci. Soc. Am. J. 65 470-479.

Scholz M 2006 Wetland systems to control urban runoff; Elsevier, Amsterdam.

Schroeder D 1979 Structure and weathering of potassium containing minerals; Proc. Congress of International Potash Institute 11 43-63.

Sparks D L 1980 Chemistry of soil potassium in Atlantic coastal plain soils: A review; Comm. Soil Sci. Plant Anal. $11435-449$.

Sparks D L 2000 Bioavailability of soil potassium; In: Handbook of Soil Science D-38-D-52 (ed.) Sumner M E, CRC Press, Boca Raton, FL.

Sposito G, LeVesque C S and Hesterberg D 1986 Calciummagnesium exchange on illite in the presence of adsorbed sodium; Soil Sci. Soc. Am. J. 50 905-909.

Stevenson F J 1986 Cycles of soils: Carbon, Nitrogen, Phosphorus, Sulfur, Micronutrients; Wiley, New York, 380p.

Stevenson F J 1994 Humus Chemistry: Genesis, Composition, Reactions; 2nd edn, John Wiley \& Sons, New York.

Tucker C J 1979 Red and photographic infrared linear combinations for monitoring vegetation; Rem. Sens. Environ. 8(2) $127-150$.

Vymazal J 2007 Removal of nutrients in various types of constructed wetlands; Sci. Total Environ. 380 48-65.

Walkley A and Black I A 1934 An examination of the Degtjareff method for determining soil organic matter, and a proposed modification of the chromic acid titration method; Soil Sci. 37 29-38.

Webster R 2000 Is soil variation random? Geoderma 97 $149-163$.

Webster R and Oliver M A 2001 Geostatistics for environmental scientists; John Wiley \& Sons, New York.

Whalen S C 2005 Biogeochemistry of methane exchange between natural wetlands and the atmosphere; Environ. Eng. Sci. 22 73-94.

Xiao C L, Ma Q and Sarigumba T 1999 Effects of soil on trace metal leachibility from paper mill ashes and sludge; J. Environ. Qual. 28 321-333.

Zhang J B, Song C C and Yang W Y 2005 Cold season $\mathrm{CH}_{4}, \mathrm{CO}_{2}$ and $\mathrm{N}_{2} \mathrm{O}$ from freshwater marshes in northeast China; Chemosphere 59 1703-1705. 